\title{
FGD4 Gene
}

National Cancer Institute

\section{Source}

National Cancer Institute. FGD4 Gene. NCI Thesaurus. Code C104379.

This gene plays a role in regulation of the actin cytoskeleton and cell shape. 